\title{
Development of Heavy Equipment Rental System Using eXtreme Programming Method
}

\author{
I Gusti Ngurah Suryantara \\ Faculty of Technology and Design, Bunda Mulia University, Jakarta, Indonesia \\ Received on 22 November 2018 \\ Accepted on 24 June 2019
}

\begin{abstract}
Many system development consultants nowadays using the XP framework (eXtreme Programming) in software development, this is based on the needs of the era where software can be completed quickly and when user software development is involved. The XP framework does not need too many team members, so it emphasizes effectiveness of work. In software development must begin with good planning to avoid patchwork (software crisis) in software development. The stage in research on the development of rental heavy equipment applications with an XP framework start from planning, designing, coding, testing and releasing software. Studies that do in this research include: literature studies, interviews, observations, document examinations. That was done as a system analysis and system design in the research. The selection of the right framework at the time of application development is very important, so that the application can be completed on time. The XP framework focuses more on making programs, the system design is enough with the CRC (Class Responsibility Collaborator). In the framework of XP, it always involves users during application development. Each module made by programmers that always tested by the system test section, so the applications that are made can be completed on time, suitable with user needs, and have high quality.
\end{abstract}

Keywords-System, Rental heavy equipment, eXtreme Programming, CRC (Class Responsibility Collaborator).

\section{INTRODUCTION}

Software requirements to a business enterprise are very important to support business processes in a company, so that various applications are developed for their needs. Enterprise has become an established discipline for business and software application management [1] [2]. Enterprise refers to a discipline that attempts to integrate, govern and analyze enterprise elements. Alignment of elements creates synergy in achieving enterprise objectives. Develop a software system, which consists of stages: plan, analysis, design, implementation, trial and management [3].

When developing the applications must be supported by good planning, so the application developed does not get patchwork. For make sure of that, this study was using the XP framework as a stage of system development. The blueprint application is very useful for every single stage when developing the system. This system lasts a long time and most consumers are already familiar with this [4].

$\mathrm{XP}$ is one of the most frequently used methodologies in agile software development;it performs continuous cooperation with the customers through the "on-site customer" practice [5]. The XP framework is one of the Agile groups. Agile methodology has a very important impact on the development of a system or program in recent years, especially this Heavy Equipment systems [6].

With the development of more adopting objectoriented programming concepts, the XP framework is suitable in accordance with the concept of objectoriented programming. This can be seen from the system design tools used, it is CRC. CRC is very appropriate to be used as a class diagram, In object oriented development within Extreme Programming, we can use CRC to design the framework on Extreme Programming, CRC or Class - Responsibility Collaboration are brainstorming tools used in object oriented software design [7].

\section{LITERATURE REVIEW}

\section{A. Analysis and Design System}

The analysis phase is a mapping of application requirements that are tailored to user needs, and design is the stage of designing a system that is made based on the business processes of the user. [8]. In creating a program with XP framework it is very right to use the object oriented programming concept. In developing the applications, can use the concept of object oriented. The four main points on the concept of object-oriented programming are: Abstraction, Encapsulation, Inheritance, Polymorphism [9].

\section{B. eXtreme Programming (XP)}

With the XP framework it provides conciseness in application development, with a small development team and in the same location. According to Kent Beck "Extreme Programming (XP) is a method of software development that is fast, efficient, low risk, flexible, predictable, scientific, and fun.". [10]. XP is the most widely used agile method and is a very well- 
known approach. Extreme Programming is based on five values that must be possessed in the work environment as well as team members [11]. XP is a software development methodology that is useful for improving the quality of software that is being created and quickly incorporating new needs from customers [12]. The XP framework as in Figure 1. XP Methodology, has stages: planning, design, coding, testing, and software increment.

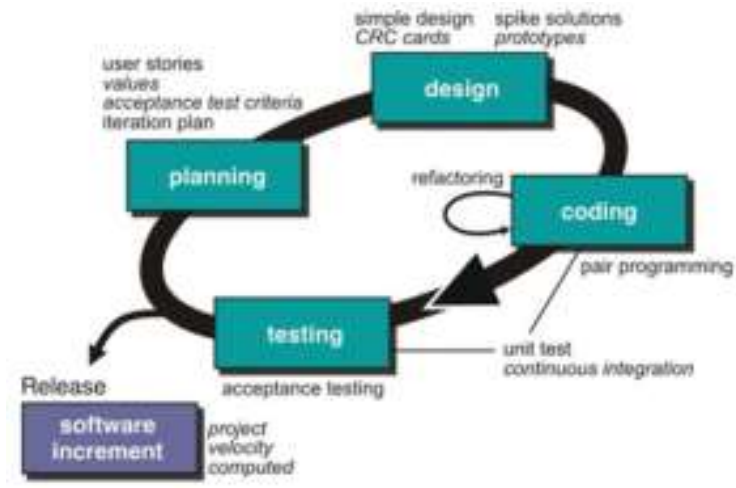

Fig.1. XP Methodology [8]

Each stage in XP as in Figure 1 will be done by the application development team, each stage will be documented. The purpose of using a framework in system development is to get a system development life cycle. The software development methodology that is almost used by all IT companies in the world is the Software Development Lifecycle. Waterfall Method, spiral method, incremental method, rational unified process (RUP), rapid application development (RAD), agile software development, and rapid prototyping are some of the SDLC methods which have been successful and tested [13], Testing process must balance the written requirements, real-world technical limitations and user expectations [14], [15], [16].

\section{Rental Heavy Equipement}

Rental Heavy equipment services are very growing rapidly, especially in countries with rapid growing of infrastructure, so the need for heavy equipment is needed. From the industrial cycle, that is how businesses emerge from the rental of heavy equipment. Addressed cost applications without considering complex factors in heavy equipment operational analyses. [17]. Construction equipment" (CE) or "Heavy equipment" refers to heavy-duty selfpropelled vehicles, specially designed for executing construction tasks [18].

\section{RESEARCH METHODS}

The need for quality software today is a challenge for software developers to avoid software crises. So the various methodologies are developed, one of them is XP (eXtreme Programming). In this study using the XP framework to help solve existing problems, with obtain the quality software, easy to develop, and there is a blueprint for software development, so as to create a life cycle of system development with an XP framework. Each part of the XP framework will be derived in detail as a research methodology. Each part of the XP framework is mapped as follows:

1. Step I Planning: in the planning stage is making user stories that obtained from interviews with users and map the output of the application desired by the user.

2. Step II Design: in the design stage with the XP framework is to create a CRC and make a prototype. CRC is used as the basic for making classes when creating programs. The prototype is the display design concept in the application.

3. Step III Coding: at this stage the activities carried out are creating a database and creating a program. The database created is grouped into master files and transaction files. The programs are divided into three, such as: master files, transaction files, and report files. In the XP framework, unit testing is also carried out when making a program.

4. Step IV Testing: this testing section is done for test the integration between modules contained in the application, so the inegration each module in the application is well

5. Step V Software Increment: at this stage is the handover of the user application. So when the application is submitted, all modules in the application are in suitable with business processes both from the developer side and from the user side.

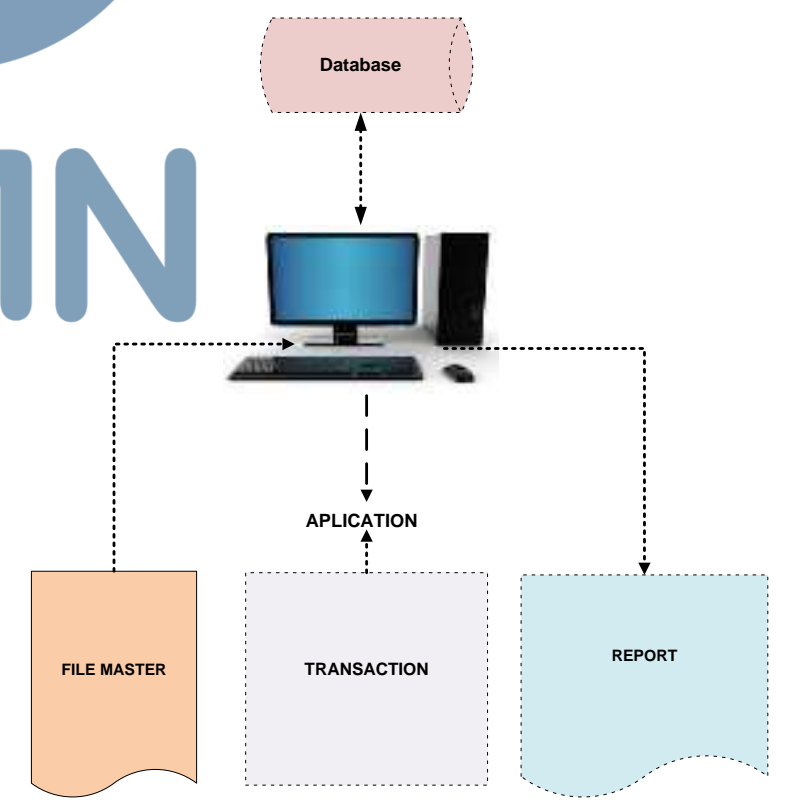

Fig.2. Step by Step of Research Methods

\section{RESULT AND ANALYSIS}

\section{A. Requirement}

Requirements application to support company performance are very needed, such as heavy equipment rental applications, heavy equipment insurance applications, distributor applications, 
staffing applications, and others. With a computerized system, various policies can be taken to realize the company's vision and mission.

\section{B. Mapping of Application}

In this research for the development of effectiveness systems, mapping requirements needs of the modules in the application is made, this mapping is very important to find out which modules are the focus of application development, see in Table 1. Module Mapping In The Application.

TABLE 1. MODULE MAPPING IN THE APPLICATION

\begin{tabular}{|c|c|}
\hline \multicolumn{2}{|c|}{ DOCUMENT NAME } \\
\hline \multicolumn{2}{|r|}{ : Heavy Equipment Rental } \\
\hline \multicolumn{2}{|r|}{ : Register of Module } \\
\hline No & Name of Module \\
\hline \multicolumn{2}{|c|}{ Master File } \\
\hline 1 & Company Name \\
\hline 2 & Units \\
\hline 3 & \multirow{2}{*}{ Brand } \\
\hline 4 & \\
\hline 5 & Color \\
\hline 6 & Status \\
\hline 7 & Heavy Equipment \\
\hline 8 & Tenant \\
\hline 9 & Currency \\
\hline \multicolumn{2}{|c|}{ Transaction File } \\
\hline 1 & Heavy Equipment Rental \\
\hline 2 & Heavy Equipment Working Hours \\
\hline 3 & Return of Heavy Equipment \\
\hline \multicolumn{2}{|c|}{ Report File } \\
\hline 1 & Heavy Equipment Rental \\
\hline 2 & Heavy Equipment Working Hours \\
\hline 3 & Return of Heavy Equipment \\
\hline \multicolumn{2}{|c|}{ User Setup } \\
\hline 1 & User setup \\
\hline
\end{tabular}
as master files, transaction files, and report files so that the application is made effectively with the XP framework. Mapping each module in the application as in table 1 .

C. Cycle of Application Heavy Equipment Rental

Cycle of application Heavy Equipment Rental in the application created as in Figure 3. Cycle of Applications.

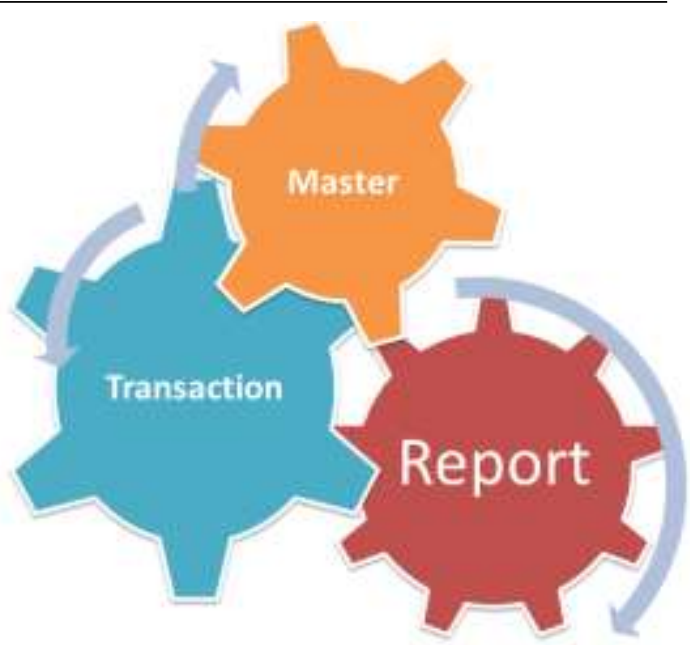

Fig.3. Cycle of Aplications

The application administrator input the master data that used in application, then input transaction data. From the application made can produce reports in the form of rental of heavy equipment, working hours of heavy equipment, and return of heavy equipment.

\section{Schedule Development}

The blueprint of application development starts from the system development framework, system design tools, database, programming, master files, transaction files, and report files. This mapping is the basis of the life cycle and application development schedule as shown in Figure 4. Life Cycle and Schedule Development.

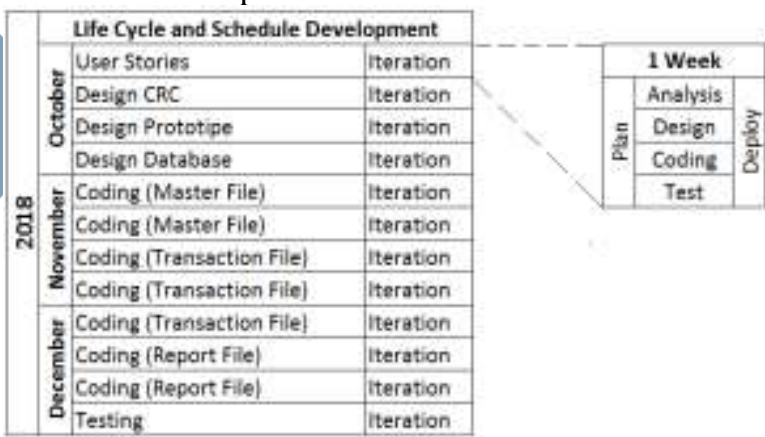

Fig.4. Life Cycle and Schedule Development

\section{E. Planning}

Every activity in application development, the application developer documenting the work. Here is the documentation to understand the business context through user stories on the XP framework that shown on table 2. User Stories. 
TABLE 2. User Stories

\begin{tabular}{|c|c|}
\hline \multicolumn{2}{|c|}{ : USER STORY } \\
\hline Name of Application & : Heavy Equipment Rental \\
\hline Activities & : Compilation of User Story \\
\hline$: 1 / 10 / 2$ & $: 1 / 10 / 2018-7 / 10 / 2018$ \\
\hline User Story & Test Cases \\
\hline $\begin{array}{l}\text { As an administrator for rental of heavy } \\
\text { equipment, I can ensure the condition } \\
\text { of each unit of equipment in good } \\
\text { condition. }\end{array}$ & $\begin{array}{l}\text { Make sure the data is } \\
\text { managed properly such } \\
\text { as the status of the } \\
\text { machine. }\end{array}$ \\
\hline $\begin{array}{l}\text { As a heavy equipment rental } \\
\text { administrator, I can properly manage } \\
\text { the data on tenants of heavy } \\
\text { equipment. }\end{array}$ & $\begin{array}{l}\text { Make sure the tenant } \\
\text { data is good managed } \\
\text { such as data search, } \\
\text { and more. }\end{array}$ \\
\hline $\begin{array}{l}\text { As an administrator for rental of heavy } \\
\text { equipment, I can record the rented } \\
\text { heavy equipment. }\end{array}$ & $\begin{array}{l}\text { Make sure that the data } \\
\text { on the rental equipment } \\
\text { is properly recorded. }\end{array}$ \\
\hline $\begin{array}{l}\text { As an administrator for rental of heavy } \\
\text { equipment, I can record the working } \\
\text { hours of heavy equipment rented. }\end{array}$ & $\begin{array}{l}\text { Make sure the machine } \\
\text { working hours are } \\
\text { recorded properly. }\end{array}$ \\
\hline $\begin{array}{l}\text { As an administrator for rental of heavy } \\
\text { equipment, I can record the equipment } \\
\text { returned by the tenant. }\end{array}$ & $\begin{array}{l}\text { Make sure the returned } \\
\text { machine is recorded } \\
\text { properly. }\end{array}$ \\
\hline $\begin{array}{l}\text { As a manager, I can see reports of } \\
\text { machines being rented. }\end{array}$ & $\begin{array}{l}\text { Make sure reports on } \\
\text { rental of heavy } \\
\text { equipment can be } \\
\text { made. }\end{array}$ \\
\hline $\begin{array}{l}\text { As a manager, I can see reports on } \\
\text { machine working hours. }\end{array}$ & $\begin{array}{l}\text { Make sure the report on } \\
\text { working hours of heavy } \\
\text { equipment can be } \\
\text { made. }\end{array}$ \\
\hline $\begin{array}{l}\text { As a manager, I can see reports on the } \\
\text { return of heavy equipment. }\end{array}$ & $\begin{array}{l}\text { Make sure reports of } \\
\text { return of heavy } \\
\text { equipment can be } \\
\text { made. }\end{array}$ \\
\hline
\end{tabular}

From the user story, it will be mapped into a story map, story map based on the user story as shown in Figure 5. Story Map, based on the story map, it is used to create a priority scale in the execution of each module contained in the heavy equipment rental application.

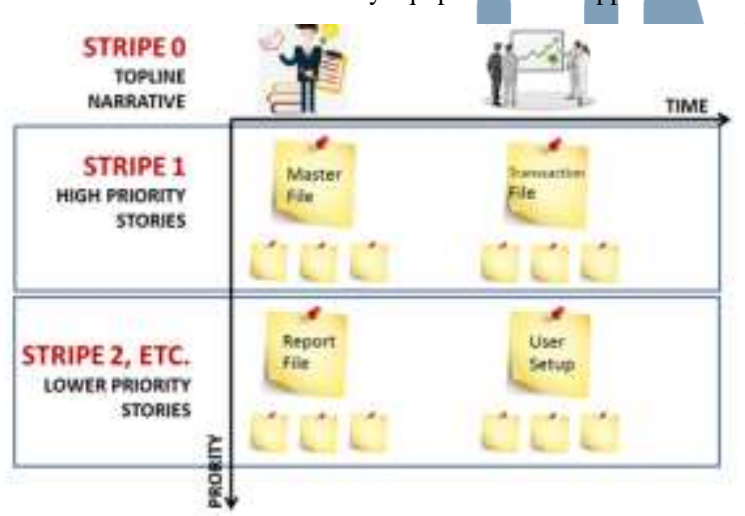

Fig.5. Story map

The business process is modeled with the use case business model, as in Figure 6. Use case business process. The administrator input all data from the master data, transaction. The leader can view all reports, and customers get rental reports, machine working hours reports, and reports on machine returns.

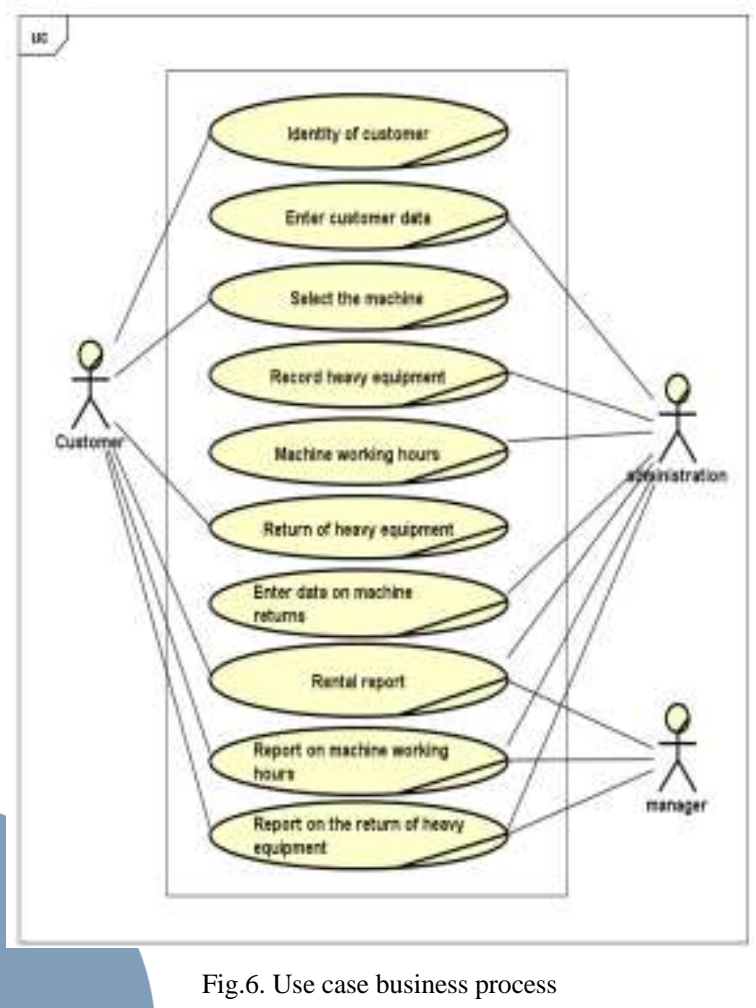

Based on user stories and business modeling, then mapped the output of application. Output on the application consists of: reports on rental of heavy equipment, reports on working hours of heavy equipment, reports on the return of heavy equipment. So that it is mapped as in Figure 7. Output on application.

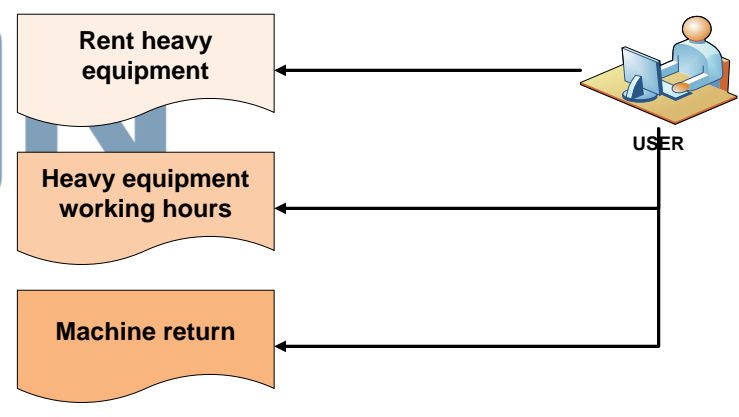

Fig.7. Output on application

Based on Figure 8 Data, application and technology architecture, shows the data architecture (containing data models), application architecture (containing each application module), and technology architecture (containing technological infrastructure). The purpose of the three architectures is to get an overview of the data that exists in each work unit, and the applications needed for each work unit, and the technology that will be applied. In this study the application developed is the rental of heavy equipment, the application will be run by two users, namely: administration that works on all the activities of the business process administration, and the manager is tasked with validating every transaction, 
such as: rental of heavy equipment, working hours weight, and return of heavy equipment.

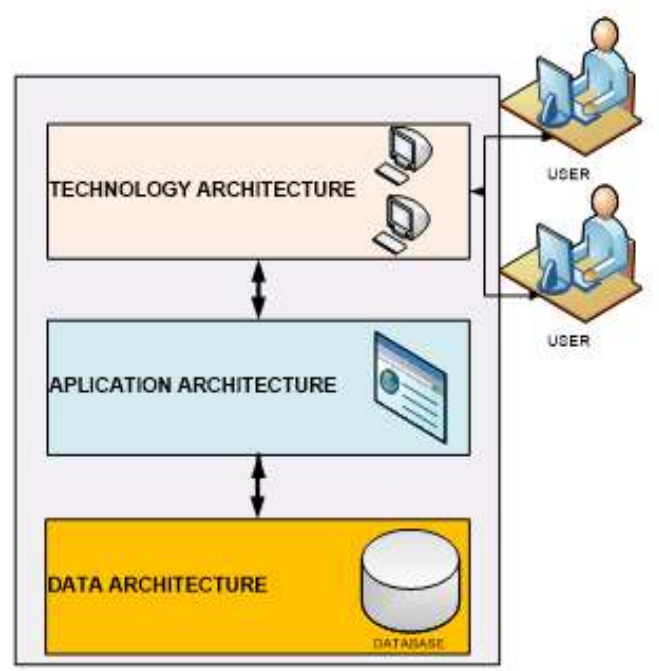

Fig.8. Data, application and technology architecture

\section{F. Design}

In the XP framework the design phase is to make CRC designs and prototypes. The requirements of CRC and prototypes can be derived from the application architecture. In table 3 Design CRC and Mapping Class, is a CRC mapping and class diagram in the application made.

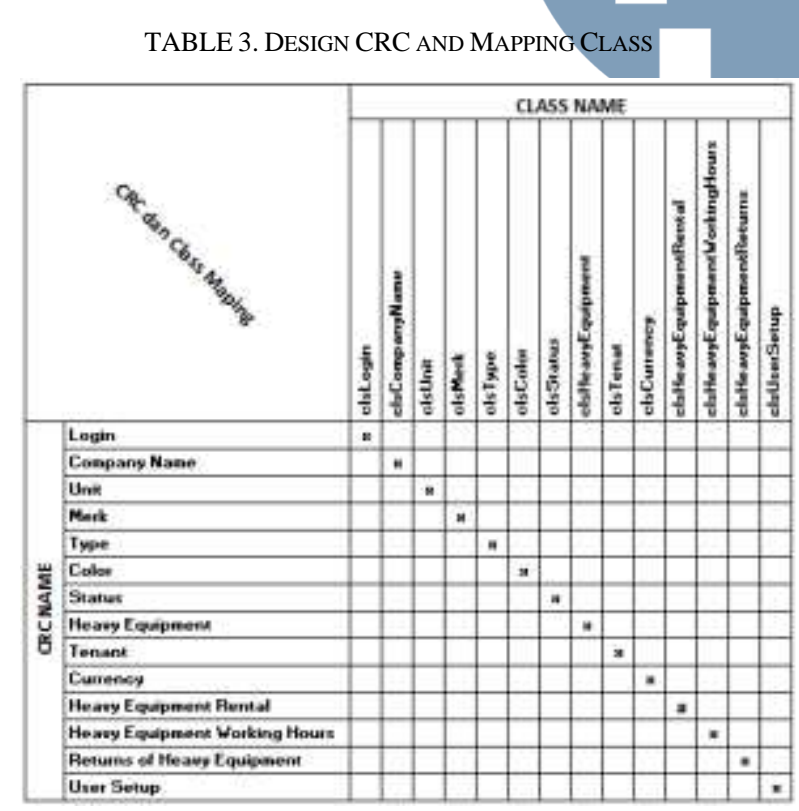

Based on table 3 which contains a mapping of CRC and class, CRC design is carried out. In figure 9 Mapping of CRC, shows an example of a CRC design. Mapping of CRC and class, it will be easier for programmers to create class structures that will be implemented into objects in the object oriented programming concept.

\begin{tabular}{|c|c|}
\hline DOCUMENT NAME & : CRC \\
\hline Name of Application & $\begin{array}{l}\text { : Heavy Equipment } \\
\text { Rental }\end{array}$ \\
\hline
\end{tabular}

\begin{tabular}{|c|c|c|c|c|}
\hline \multirow{2}{*}{\multicolumn{2}{|c|}{$\frac{\text { Activities }}{\text { Period }}$}} & \multicolumn{3}{|c|}{ : Design CRC } \\
\hline & & & & - \\
\hline No & & \multicolumn{3}{|c|}{$\begin{array}{l}15 / 10 / 2018 \\
\text { CRC }\end{array}$} \\
\hline \multirow[t]{17}{*}{1} & & \multicolumn{2}{|c|}{ COMPANY NAME } & \\
\hline & & Superclasses & - & \\
\hline & & Subclasses & - & \\
\hline & & Responsibilities & Collaborators & \\
\hline & & Company & & \\
\hline & & Address & & \\
\hline & & Ip Code & & \\
\hline & & Fax & & \\
\hline & & E-Mali & & \\
\hline & & Tax Number & & \\
\hline & & Bank Name & & \\
\hline & & No. A/C & & \\
\hline & & Name & & \\
\hline & & Save & & \\
\hline & & Exit & & \\
\hline & \multirow{2}{*}{\multicolumn{4}{|c|}{ Company name CRC can be modeled into a class. }} \\
\hline & & & & Etc \\
\hline
\end{tabular}

Fig.9. Mapping of CRC

Furthermore, mapping is carried out to the prototypes requirements in the application made. Mapping for prototype requirements can be derived from the CRC mapping table, in Figure 10 Prototype Mapping, shows an example of a prototype.

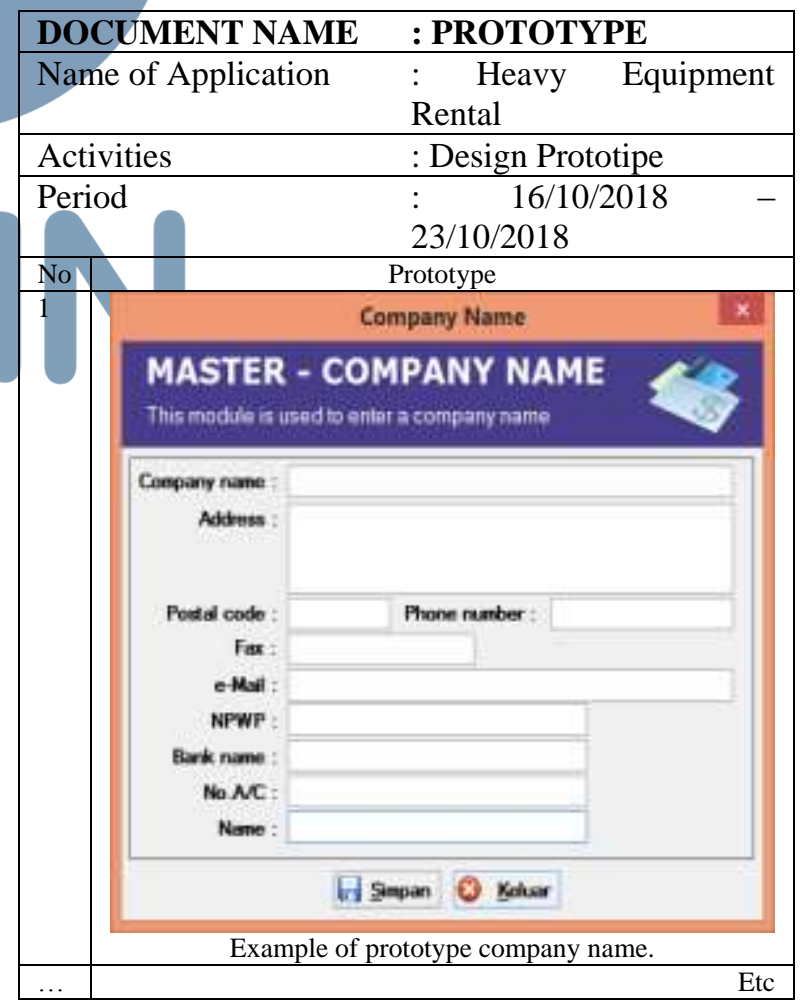

Fig.10. Prototype Mapping

Because the limitations of this paper, one example of the prototype design is the master name of the company. 


\section{G. Coding}

The coding phase is done by two job, such as: creating a database and creating a program. In the coding stage, you can also test the system. Based on table 4. Mapping of Tables In Database, show the mapping of table requirements in the database.

TABLE 4. MAPPING OF TABLES IN DATABASE

\begin{tabular}{|c|c|c|c|}
\hline \multicolumn{2}{|c|}{ No } & & Description \\
\hline \multirow{11}{*}{$\begin{array}{l}\frac{\pi}{12} \\
\frac{1}{2} \\
\frac{1}{2}\end{array}$} & 1 & tblCName & To save data copany name \\
\hline & 2 & tblMJenis & To save data type \\
\hline & 3 & tblMBrand & To save data brand \\
\hline & 4 & tblMCurrency & To save data currency \\
\hline & 5 & tblMTenant & To save data tenant \\
\hline & 6 & tblMRate & To save data rate \\
\hline & 7 & tblMStatus & To save data status \\
\hline & 8 & tblMUnits & To save data units \\
\hline & 9 & tblMType & To save data type \\
\hline & 10 & tblMColor & To save data color \\
\hline & 11 & tblMUser & To save data user \\
\hline \multirow{6}{*}{ 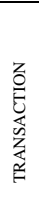 } & 1 & tblTHRental & To save data header rental \\
\hline & 2 & tblTDRental & To save data detail rental \\
\hline & 3 & tblTHHours & To save data header hours \\
\hline & 4 & tblTDHours & To save data detail hours \\
\hline & 5 & tblTHReturn & To save data header return \\
\hline & 6 & tblTDReturn & To save data detail return \\
\hline
\end{tabular}

Based on Table 5 User Interface Mapping show a mapping of requirements user interface design.

TABLE 5. USERINTERFACE MAPPING

\begin{tabular}{|c|c|c|c|}
\hline \multicolumn{2}{|l|}{ No } & Form Name & Description \\
\hline \multirow{11}{*}{ 坫 } & 1 & frmLogin & $\begin{array}{l}\text { For login to } \\
\text { application }\end{array}$ \\
\hline & 2 & frmCompanyName & $\begin{array}{l}\text { For logs company } \\
\text { name }\end{array}$ \\
\hline & 3 & frmUnits & For logs units \\
\hline & 4 & frmBrand & For logs brand \\
\hline & 5 & frmType & For logs type \\
\hline & 6 & frmColor & For logs color \\
\hline & 7 & frmStatus & For logs status \\
\hline & 8 & frmHeavyEquipment & $\begin{array}{l}\text { For logs heavy } \\
\text { equipment }\end{array}$ \\
\hline & 9 & frmTetnant & For logs tenant \\
\hline & 10 & frmCurrency & For logs currency \\
\hline & 11 & frmUserSetup & For logs setup \\
\hline \multirow{3}{*}{ 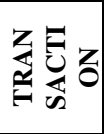 } & 1 & frmHERental & For logs rental \\
\hline & 2 & frmHEWorkingHours & $\begin{array}{l}\text { For logs working } \\
\text { hours }\end{array}$ \\
\hline & 3 & frmHEReturns & For logs return \\
\hline \multirow{3}{*}{ 点 } & 1 & frmPrintRental & For print rental \\
\hline & 2 & frmPrintWorkingHours & $\begin{array}{l}\text { For print working } \\
\text { hours }\end{array}$ \\
\hline & 3 & frmPrintRetun & For print return \\
\hline
\end{tabular}

Based on Figure 11 Documentation Table, shows the documentation mapping the design of the tables in the database. Because of the limitations of this paper, one example is shown.

\begin{tabular}{|c|c|c|c|c|c|}
\hline \multicolumn{4}{|c|}{ DOCUMENT NAME } & : TABLE & \\
\hline \multicolumn{4}{|c|}{ Name of Application } & \multicolumn{2}{|c|}{ : Heavy Equipment Rental } \\
\hline \multicolumn{4}{|c|}{ Activities } & \multicolumn{2}{|c|}{ : Design Table } \\
\hline \multicolumn{4}{|c|}{ Period } & \multicolumn{2}{|c|}{$: 24 / 10 / 2018-31 / 10 / 2018$} \\
\hline No & & & Table & & Description \\
\hline \multirow[t]{4}{*}{1} & \multicolumn{4}{|c|}{ Z7 tomtype } & \multirow{4}{*}{$\begin{array}{l}\text { Example of } \\
\text { table type. }\end{array}$} \\
\hline & \multirow{3}{*}{8} & Field Nanie & Data Type & \multirow{2}{*}{ Field Size 4} & \\
\hline & & kDType & Text & & \\
\hline & & Type & Text & Fleld size 30 & \\
\hline \multirow[t]{4}{*}{2} & \multicolumn{4}{|c|}{ tbimStatus } & \multirow{4}{*}{$\begin{array}{l}\text { Example of } \\
\text { table status. }\end{array}$} \\
\hline & \multirow{3}{*}{8} & Field Name & Data Type & & \\
\hline & & KDStatus & Text & Field Size 4 & \\
\hline & & Status & Text & Field Size 20 & \\
\hline$\ldots$ & $\ldots$ & & & & Etc \\
\hline
\end{tabular}

Fig.11. Documentation Table

Based on figure 12 Documentation of Coding ,shows the documentation of the interface mapping in the application. Making interfaces based on mapping the prototype that has been mapped before. Because of the limitations of this paper, one example is shown.

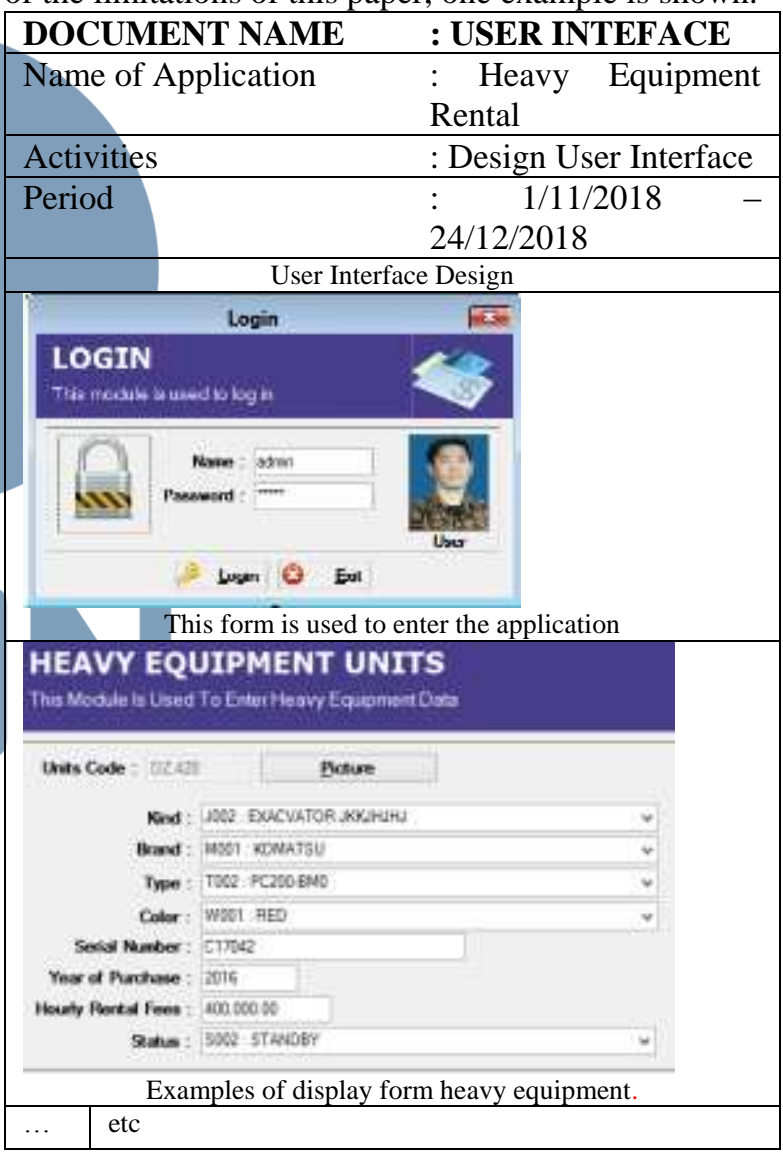

Fig.12. Documentation of Coding

H. Testing

XP framework, also do the final testing before the application is submitted to the user. Many system test methods can be done such as black box, white box, and others. XP using unit testing, in table 6 Unit Testing Mapping, shows each module tested with unit testing and all modules are in accordance with the business process with the statement are Ok. 
TABLE 6. UNIT TESTING MAPPING

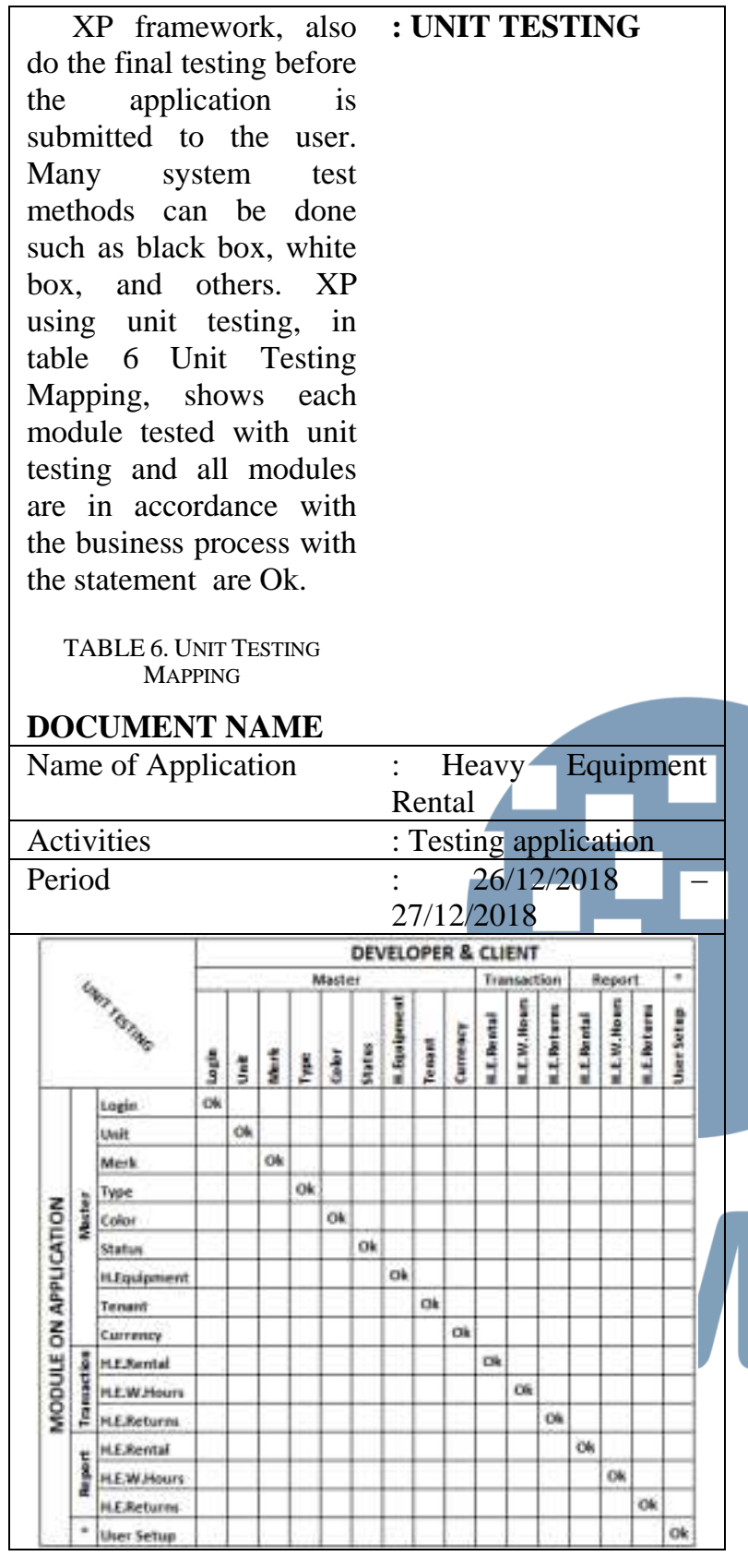

Testing is a very important stage in the development of applications, with testing providing quality assurance software developed so that users get quality software. In this study using unit testing. The most "micro" scale of testing; to test particularfunctions or code modules. Typically done by the programmer and not by testers, as it requires detailed knowledge of the internal program design and code. [19].

\section{Software Increment}

Software Increment is releasing applications to users, with the release of applications to users each module in the application is synchronized from the developer and user side. Synchronization between the two parties when mapped into a matrix must forming a diagonal in an "Ok" state. Synchronization is mapped on table 7. Synchronization. After going through the software increment, which is marked by the release of the application to the user, the life cycle of application development with the work of eXtreme Programming has entered the final part of the activities in eXtreme Prorgamming. In this section it contains training for users to run applications, care for applications on a regular basis, so that applications that are made really have no obstacles during use by users. This stage, the application is handed over to the user and can also be closed with a marking of document, the application has been completed can be used by the user.

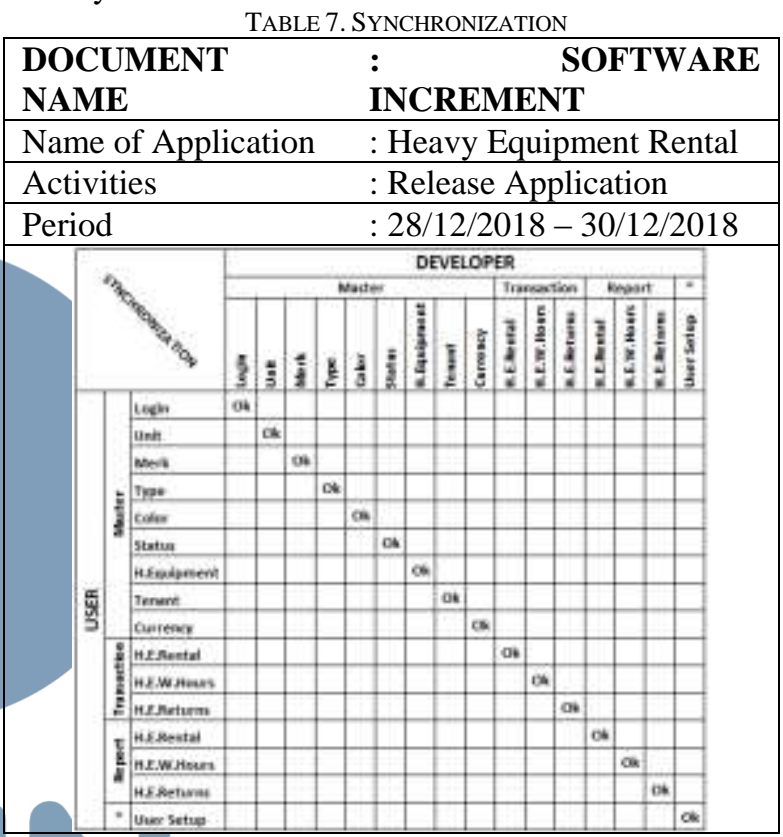

The developer also documents the application handover documentation from the developer to the user in the form of an application handover agreement letter.

\section{CONCLUSIONS}

Life Cycle and system development blueprint are very important in system development, so we need a system development framework in developing the system.

The XP framework is very suitable for dynamic system development, while XP always allows changes during system development to get applications that suit the user's needs.

The advantage of the XP framework in system development is the involvement of team is small, but has a very high productivity in system development.

The application made in this research is a heavy equipment rental application using the XP framework that tested with unit testing in each module.

In the XP framework the important thing is user's involvement in system development, mastery of CRC mapping and object-oriented programming, because 
the XP framework is very suitable in accordance with the concept of object-oriented programming.

\section{REFERENCES}

[1] Robert Lagerström, Carliss Baldwin, Alan MacCormack, David Dreyfus, Visualizing and Measuring Enterprise Architecture: An Exploratory BioPharma Case Working Paper 13-105, June 28, 2013, Harvard Business School.

[2] Ross, J.W., Weill, P., Robertson, D.: Enterprise Architecture As Strategy: Creating a Foundation for Business Execution. Harvard Business School Press, 2006.

[3] Susanto HM, Mantja W, Bafadal I, Sonhadji A. Pengembangan Sistem Informasi Manajemen Pendidik dan Tenaga Kependidikan. J Pendidik Hum, 3(2), pp. 93-105, 2015.

[4] Saxena N., John J.S., Manasvee G., Jun Y.J.C., Michael G., Oliver N.H., and David C.S., "Consumer Perceptions of Mobile and Traditional Point-of-Sale Credit/Debit Card Systems in the United States: A Survey", International Journal of Cyber Criminology (IJCC), Vol 9, Issue 2, pp. 162-172, 2015.

[5] Shahriar Mohammadi Bahman Nikkhahan Sahar Sohrabi, Challenges of user Involvement in Extreme Programming projects, International Journal of Software Engineering and Its Applications, Vol. 3, No. 1, January, pp. 19-32, 2009

[6] A. Hameed, "Software Development Lifecycle for Extreme Programming," Int. J. Inf. Technol. Electr. Eng. ITEE, Vol. 5, no. 1, pp. 7-13, 2016.

[7] I. Ghani and I. Yasin, "Software Security Engineering In Extreme Programming Methodology: A Systematic Literature," Sci. Int., vol. 25, no. 2, pp. 215-221, 2013.

[8] I. G. N. Suryantara and J. F. Andry, "Development of Medical Record With Extreme Programming SDLC," IJNMT, Vol. V, no. 1, pp. 47-53, 2018.

[9] I.G.N. Suryantara, "Merancang Aplikasi Rekam Medis Dengan VB.Net," Elex Media Komputindo, Jakarta, 2015

[10] R. Agarwal and D. Umphress, "Extreme programming for a single person team," Proc. 46th Annu. Southeast Reg. Conf. XX - ACM-SE 46, p. 82, 2008.

[11] P. Kolte, T. Bhujbale, and A. Chaware, "Web Portal Development using Extreme Programming Practices," Int. Conf. Recent Trends Inf. Technol. Comput. Sci., pp. 32-37, 2012.

[12] P. Kolte, T. Bhujbale, and A. Chaware, "Web Portal Development using Extreme Programming Practices," Int. Conf. Recent Trends Inf. Technol. Comput. Sci., pp. 32-37, 2012.

[13] Y. Bassil, "A Simulation Model for the Waterfall Software Development Life Cycle," Int. J. Eng. Technol., vol. 2, no. 5, pp. 2049-3444, 2012.

[14] S. M. K. Quadri, "Software Testing-Goals, Principles, and Limitations," vol. 6, no. 9, pp. 7-10, 2010.

[15] J. Khojasteh, T. S. Zeki, and H. Reza, "A Functional Testing Modeling for Enhanced Software Testing," vol. 2, no. 10, pp. 738-741, 2012.

[16] Andry, J.F., Suroso., J.S., Bernanda, D.Y.,Improving Quality of SMEs Information System Solution with ISO 9126 , Journal of Theoretical and Applied Information Technology, 96(14) (2018), pp. 4610-4620.

[17] A. Jrade, N. Markiz, and N. Albelwi, An Economical Operation Analysis Optimization Model for Heavy Equipment Selection, World Academy of Science, Engineering and Technology, International Journal of Economics and Management Engineering Vol:6, No:1, 2012

[18] Ilias Naskoudakis, Kleopatra Petroutsatou, A Thematic Review of the Main Research on Construction Equipment over Recent Years, Periodica Polytechnica Architecture, 47(2), pp. 110-118, 2016.
[19] William E. Lewis. Software testing and continuous quality improvement. third edition. Auerbach Publications, Taylor \& Francis Group, 2009. 